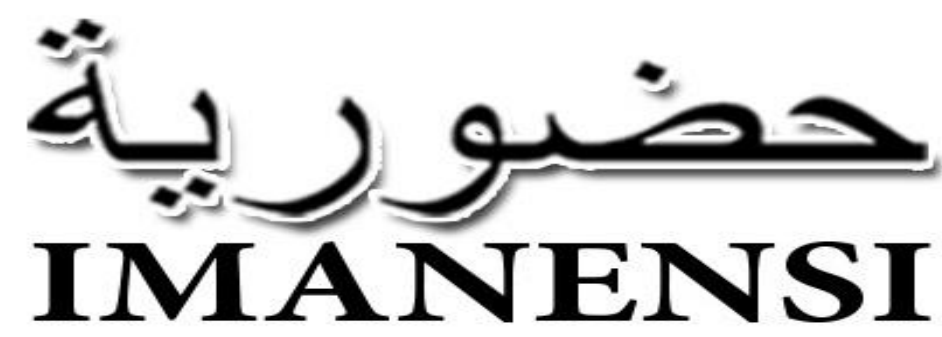

(Jurnal Ekonomi, Manajemen, dan Akuntansi Islam) Vol 2, No 2, September 2017, Hlmn. 7-17

\title{
Mengintai akuntansi dari balik topeng malang
}

Darti Djuharnia, Yudib, Novrida Qudsi Lutfillahc

a STIE Malangkucecwara, Indonesia 65141

b Universitas Jambi, Indonesia 36122

c Universitas Wjaya Putra, Indonesia 60197

1*dartidjuharni@yahoo.com

\begin{abstract}
Abstrak
Tujuan penelitian adalah untuk mengintai makna akuntansi dari balik tari topeng Malangan. Penelitian ini merupakan penelitian kualitatif menggunakan metafora tontonan, tuntunan dan tatanan tari topeng. Hasil Penelitian menunjukkan tontonan dalam akuntansi dapat dilihat oleh penggunanya melalui laporan keuangan. Kondisi ini bisa dikaitkan dengan Neraca yang tampak pada keseimbangan debet dan kredit. Tatanan penyajian laporan keuangan juga memuat aturan yang harus diikuti dan ditaati berdasarkan standar akuntansi yang berlaku umum seperti standar akuntansi keuangan (SAK) dan SAK_ETAP. Laporan keuangan harus pula mengandung tata nilai atau norma yang merupakan tuntunan dan diperlukan dalam menyusun laporan keuangan.
\end{abstract}

Kata Kunci: Akuntansi; Budaya Malangan; Makna Akuntansi.

\begin{abstract}
The aim of the study was to stalk the accounting meaning from behind the Malangan mask dance. This research is a qualitative research using spectacle metaphor, guidance and order in mask dance. Research Results show the spectacle in accounting can be seen by users through financial statements. This condition can be corrected with a balance sheet that appears on the debit and credit balance. The order of presentation of financial statements also announces rules that must be followed and adhered to based on generally accepted accounting standards such as financial accounting standards (SAK) and SAK_ETAP. Financial statements must also contain a value or norm that completes and needs to complete financial statements.
\end{abstract}

Keywords: Accounting; Malangan Culture; Accounting Meanings.

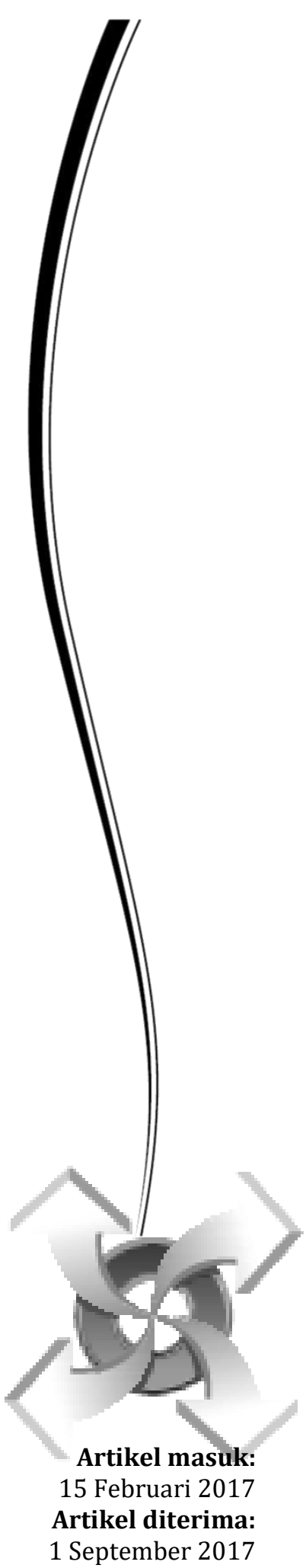


Modernisasi dan pembangunan telah membawa masyarakat ke dalam berbagai sisi realitas kehidupan baru, seperti kenyamanan, kesenangan, penampilan, dan kebebasan berhasrat. Di sisi lain, Giddens menangkap adanya "ancaman besar berupa kehampaan makna pribadi" yang menyebabkan hilangnya nilai-nilai dan kearifan-kearifan dalam realitas masa lalu yang ada dibaliknya (Ritzer \& Goodman, 2012, pp. 610-611). Padahal, nilai-nilai ini justru sangat berharga bagi pembangunan rasa diri sebagai manusia seperti, rasa kedalaman, rasa kebersamaan, rasa keindahan, semangat spiritualitas, semangat moralitas, dan semangat komunitas. Di bidang akuntansi, pengembangannya berlangsung dalam suasana kapitalistik dan materialistik budaya Amerika khususnya dan budaya Barat umumnya (Ludigdo, 2005, p. 196). Tentu saja wacana dan praksis akuntansi menjadi kental dengan dimensi individualisme.

Dimensi individualisme merupakan orientasi utama budaya Amerika dan budaya Barat yang menekankan pada kapitalistik dan materialistik sehingga kegiatan dan kejadian ekonomipun berorientasi pada "return on Investment". Hal itu menjadi kontras jika dibandingkan dengan budaya Indonesia yang kental dengan dimensi kolektivisme sebagaimana disampaikan oleh Hofstede, Hofstede, and Minkov (2010, p. 118). Dimensi kolektivisme lebih menekankan pada rasa kebersamaan dan kekeluargaan, sehingga kegiatan dan kejadian ekonominya lebih berorientasi pada "return on favor". Ludigdo (2005, p. 196) melihat orientasi ini parallel dengan idiom Jawa dalam berbisnis yaitu "rugi sathak bathi sanak". Wacana dan praktik akuntansi yang selalu mengacu kepada budaya Barat tentu saja memberi ruang sempit bagi konteks lokalitas bangsa Indonesia yang justru kaya akan nilai sesuai dengan kebutuhan dan karakter masyarakatnya. Transformasi menghilangnya nilai-nilai tersebut terjadi melalui pengalaman terhadap objek-objek dan media-media (massa) dalam satu ruang dan waktu yang membatasinya, baik secara sadar maupun tak sadar.

Pilliang (1999, p. 225) mengatakan bahwa proses transformasi dalam membangun citra diri dan menyusun makna kehidupan sebenarnya terjadi melalui ketidaksadaran massal. Sementara, Baudrillard (1983, p. 2) melihat bahwa penciptaan dunia kebudayaan yang memuat nilai-nilai mengikuti satu model produksi yang disebut dengan simulasi. Melalui model simulasi, manusia terjebak dalam satu ruang yang disadarinya sebagai realitas nyata. Padahal, realitas yang dihadapi sesungguhnya semu atau khayalan belaka. Realitas-realitas simulasi menjadi ruang kehidupan baru tempat manusia menemukan dan mengaktualisasikan eksistensi dirinya. Dunia simulasi tampil secara sempurna melalui televisi.Inilah ruang yang tak lagi peduli dengan kategori-kategori nyata, semu, benar, salah, referensi, representasi, fakta, citra, produksi, reproduksi semuanya lebur menjadi satu dalam silang sengkarut tanda (Piliang, 1999, p. 225). Melalui televisi realitas tidak hanya diproduksi, disebarluaskan atau direproduksi, tetapi juga dimanipulasi.

Terkait dengan model simulasi pada uraian sebelumnya, dalam tulisan ini ingin diintai makna akuntansi dari balik tari topeng Malangan. Seni Tari Topeng Malangan merupakan salah satu bentuk tari dan cerita yang diperankan oleh berbagai tokoh denganmenggunakan topeng. Berbagai bentuk atau karakter topeng dapat diperagakan sesuai karakter yang diperankan oleh penarinya dan dikomentari oleh dalang. Dari pagelaran tari topeng itu penonton dapat mencari makna dari simbolsimbol yang ada.Simbol itu dapat dilihat dari bentuk topeng, gerakan tari, ataupun dari parik'an (pantun Jawa berupa sindiran) yang disampaikan oleh dalang.

Sehubungan dengan simbol topeng yang dikaitkan dengan akuntansi, Macintosh (2003) menjelaskan bahwa banyak simbol akuntansi yang tidak memiliki rujukan obyek atau peristiwa. Akibatnya, akuntansi tidak secara penuh menjalankan fungsinya sebagai logika representasi, alat pertanggungjawaban, atau alat penyajian informasi ekonomik. Sebagai contoh, pada penyajian laporan laba-rugi seharusnya diungkap informasi laba sesuai dengan bingkai penafsiran pragmatis (Riduwan, Triyuwono, Irianto, \& Ludigdo, 2009), tetapi pelaporan informasi laba-rugi tidak hanya mengunggulkan idealisme, karena para pengguna akhir berada dalam habitus pragmatic. Kemajuan teknologi informasi dan komunikasi juga mereduksi nilai-nilai luhur dari sebuah komunitas. Kemajuan ini juga mereduksi realitas itu sendiri, dan 
tidak sekedar hanya diceritakan, direpresentasikan, dan disebarluaskan tetapi juga dapat dibuat, direkayasa, dan disimulasi.

\section{METODE}

Artikel ini merupakan hasil penelitian kualitatif dengan menggunakan metafora tontonan, tuntunan, dan tatanan. Istilah metafora digunakan karena menggunakan kata atau kelompok kata bukan dengan arti yang sebenarnya. Pilliang (2003, p. 262) menyatakan bahwa metafora adalah sebuah interaksi tanda, yang didalamnya berisi sebuah tanda dari sebuah sistem yang digunakan untuk menjelaskan makna dalam sebuah sistem yang lain. Sedangkan Budiman (1999, p. 73) menjelaskan bahwa gambar, skema, dan peribahasa merupakan bagian dari apa yang disebut sebagai metafora. Selanjutnya Ricoeur (2006, p. 229) mengingatkan bahwa penggunaan metafora harus sesuai dengan konteksnya agar makna yang muncul merupakan hasil dari konteks tersebut. Sehubungan dengan hal tersebut, maka tontonan, tuntunan, dan tatanan digunakan sebagai analisis data dalam tulisan ini. Sedangkan untuk mengumpulkan data digunakan dengan metode wawancara.

Menurut Sutopo (2002, p. 59) dalam penelitian kualitatif, wawancara dilakukan tidak terstruktur atau sering di sebut dengan wawancara mendalam. Dimana wawancara dilakukan dalam suasana tidak formal dan dengan pertanyaan yang mengarah pada kedalaman informasi. Subyek yang diteliti berperan sebagai informan, sehingga sumber data dalam penelitian ini adalah informan dan dari literature yang ada kaitannya dengan pembahasan. Spradley (1997, p. 47) menyatakan bahwa informan diposisikan sebagai pemberi informasi tentang 1) kebudayaan yang dimiliki, 2) konsep yang digunakan untuk mengklasifikasikan pengalaman mereka, 3) bagaimana mereka mendefinisikan konsep kebudayaan yang mereka miliki. Pemilihan informan dilakukan melalui beberapa pertimbangan yaitu: Bapak Sunari adalah salah seorang budayawan Malang yang paham betul tentang budaya Malang, selain itu beliau adalah seorang sarjana Seni dan Tari yang kegiatan sehari-harinya adalah mengajar tari dan lukis bagi siswa sekolah internasional di Malang. Disamping itu beliau juga membuka sanggar lukis dan tari di rumahnya untuk memberi pelatihan tari dan lukis kepada masyarakat umum. Beliau memiliki semua peralatan dan pakaian tari topeng dan paham betul tentang makna ornamen pada setiap bentuk topeng, serta mampu memberikan pemahaman kepada pengerajin topeng bagaimana seharusnya topeng diproduksi dan dirawat. Berdasarkan hal tersebut, maka Pak Sunari dianggap sebagai informan yang memenuhi syarat.

Sekilas tentang Budaya Malang. Malang merupakan salah satu kota di Jawa Timur yang terletak kurang lebih $90 \mathrm{~km}$ sebelah selatan kota Surabaya. Berbagai julukan diberikan orang untuk kota Malang, beberapa di antaranya adalah Parish Van Java, Kota Apel, Kota Pelajar, Kota Dingin, dan Kota Wisata (Aamaah, 2011). Berbagai julukan yang diberikan itu tidak lepas dari banyaknya wisatawan yang berkunjung ke Malang. Pada tahun 2012 jumlah wisatawan yang datang ke Malang meningkat 300 $\%$ dibandingkan tahun sebelumnya (Rsm, 2013). Agar para wisatawan paham tentang Malang, maka perlu diperkenalkan budaya dan sejarah Malang melalui berbagai media seperti pagelaran, pameran, ataupun kegiatan-kegiatan lain yang dapat dilakukan untuk menunjukkan Malang sebagai salah satu tujuan wisata. Salah satu pagelaran yang sering diadakan untuk memberi pemahaman kepada masyarakat adalah pagelaran seni tari topeng Malangan. Ketika mewawancarai Pak Sunari (Informan) beliau menjelaskan tentang budaya Arek. Sebagaimana petikan wawancara berikut ini:

"Kebudayaan Malang sebetulnya terbagi dalam sub-sub. Campuran dari Kanjuruhan dan Singosari melahirkan budaya Arek. Ini asli Malang.Sub lainnya adalah subMataraman, ini terletak di selatan Malang. Merupakan budaya yang datang dari Jawa Tengah, jadi ngomongnya pakai Piye-piye. Ada juga perkawinan orang Jawa Madura yang sebelah timur Malang, menghasilkan sub budaya Pendalungan".

Selanjutnya, petikan wawancara mengenai tontonan, tuntunan dan tatanan, sebagai berikut: 
"Dalam Kesenian wayang mengandung tontonan, tuntunan dan tatanan. Tuntunan itu secara lahir yaa. Kalau tuntunan peperangan dengan jahat dan baik. Semua Kesenian yang berasal dari wayang selalu mengandung ini. Zaman dulu pesan moral sudah lebih halus. Peperangan jahat dan baik, dalam topeng di beri nama kelana jowo yang merupakan orang baik, sedang kelana sebrang identik dengan jahat". "Sebetulnya aturan dari wayang topeng Malangan merupakan tuntunan batin. Kalau tontonan kan yang lahir (maksudnya lahiriyah) sedang tatanan kalau sripanggung sesuai dengan alur cerita, dalam tatanan kehidupan sehari-hari berhubungan dengan sopan santun yang saat ini masih ada pada anak muda Malang"

Berdasarkan petikan wawancara tersebut, dapat diambil benang merahnya, bahwa topeng Malang merupakan salah satu bentuk budaya Malang yang disebut dengan budaya Arek. Budaya ini terjadi karena adanya pertemuan dari tiga subkultur; (1) Jawa Tengah (Mataraman) yaitu daerah Malang Selatan, (2) Madura (Pendalungan) daerah Malang Timur, dan (3) Arek yang terletak di pusat kota Malang.Lebih lanjut tari topeng merupakan tontonan, tuntunan, dan tatanan.tontonan, tari topeng merupakan pagelaran seni yang dapat disaksikan dan dinikmati oleh masyarakat luas; sebagai tuntunan karena cerita yang dikisahkan dalam pagelaran itu mengandung nilai-nilai moral yang ingin disampaikan kepada masyarakat, selain itu dalang sering menggunakan parikan (pantun Jawa) untuk menyindir para penonton yang bertingkah kurang sopan atau tidak sepatutnya; dansebagai tatanan karena para penari bermain sesuai alur cerita yang telah ditetapkan oleh sutradara yang mengatur pagelaran tari topeng. Selain itu, sutradara juga melakukanpengaturanterhadaptataletakpanggung dan kostum penari sesuai dengan skenario pagelaran.

Model simulasi, mitos, dan simbol menjebak ke dalam realitas semu. Tari topeng mengandung nilai-nilai moral melalui simulasi, mitos dan simbol-simbol. Hal ini sejalan dengan Baudrillard (1983, p. 2) yang juga melihat bahwa penciptaan kebudayaan memuat nilai-nilai yang mengikuti satu model produksi yaitu simulasi. Melalui model simulasi, manusia terjebak dalam satu ruang yang disadarinya sebagai realitas nyata. Padahal, realitas yang dihadapi sesungguhnya adalah semu atau khayalan belaka. Ruang realitas semu merupakan satu ruang antitesis dari representasi.Analoginya, bila dalam ruang nyata sebuah peta merupakan representasi dari sebuah teritorial, maka di dalam model simulasi, petalah yang mendahului teritorial.

Realitas teritorial sosial, kebudayaan, atau politik kini dibangun berlandaskan model-model (peta) fantasi yang ditawarkan melalui televisi, iklan, bintang-bintang layar perak, atau tokoh-tokoh kartun (Piliang, 1999, p. 228). Tempat-tempat seperti Disneyland, Stadion Wembley, danbintang film seperti Madonna dan bintang sepakbola seperti Maradona, atau tokoh kartun seperti Mickey Mouse dan Doraemon merupakan model dalam membangun citra-citra, nilai-nilai dan makna-makna dalam kehidupan sosial, kebudayaan, serta politik.Dalam wacana simulasi, model ini membuat manusia seolah-olah mendiami suatu ruang realitas dimana perbedaan antara yang nyata dan fantasi, sertayang asli dan palsu sangat tipis.Manusia kini hidup dalam ruang khayali yang nyata, sebuah fiksi yang faktual.Realitas-realitas simulasi menjadi ruang kehidupan baru tempat manusia menemukan dan mengaktualisasikan eksistensi dirinya.Dunia simulasi tampil secara sempurna melalui media elektronik seperti televisi dan media online.Melalui televisi dan media online realitas tidak hanya diproduksi, disebarluaskan, atau direproduksi, tetapi juga dimanipulasi.

Masyarakat modern mengembangkan strategi mitos, bukan mitos masa lalu tetapi mitos masa kini. Kemampuan mengembangkan mitos dipercaya menjadikan masyarakat modern survive sekarang ini. Pemahaman akanmitos penting juga bagi setiap masyarakat modern, karena di dalamnya terdapat kekuatan untuk memengaruhi atau menanamkan suatu kepercayaan yang berarti kekuasaan. Jika kita tidak mengetahui mitos yang berkembang maka kita akan selalu berada dalam 
ketertindasan. Model interaksi seperti inilah yang saat ini terjadi di dalam percaturan masyarakat modern, dalam membentuk wacana.

Agency Theory Representasi Realitas dan Makna. Agency theory yang dimaksud oleh Jensen dan Meckling (1976) adalahhubungan antara agen (manajemen/manajer suatu usaha) dengan prinsipal. Di dalam hubungan keagenan terdapat suatu kontrak dimana satu orang atau lebih (prinsipal) memerintah orang lain dalam hal ini adalahagen, untuk melakukan jasa atas nama prinsipal dan memberi wewenang kepada agen membuat keputusan yang terbaik bagi prinsipal. Informasi laporan keuangan yang disampaikan secara tepat waktu akan mengurangi asimetri informasi yang erat kaitannya dengan teori keagenan, sehingga dalam hubungan keagenan, manajemen diharapkan dapat mengambil kebijakan terutama kebijakan keuangan yang menguntungkan pemilik perusahaan. Bila keputusan manajemen merugikan pemilik perusahaan maka akan timbul masalah keagenan (Ismiyanti \& Hanafi, 2004, p. 176).

Masalah keagenan dapat memengaruhi konservatisme akuntansi (Widanaputra dalam Putri, 2011). Konsep konservatisme merupakan praktik akuntansi yang digunakan untuk mengurangi laba atau adanya pemilihan pencatatan akuntansi dengan memilih metode akuntansi yang mencatat pendapatan lebih rendah dan biaya yang lebih tinggi. Untuk memperoleh laba yang lebih tinggi agenpun melakukan manajemen laba. Akuntansi konvensional melegalkan praktik manipulasi laba yang mementingkan kepentingan pribadi (self interest) melalui kebijakan diskresi akrual dan theory agency (Jensen \& Meckling, 1976). Kebijakan ini memberikan konsekuensi munculnya bonus plant hypothesis, debt covenant hypothesis, dan political cost hypothesis (Watts \& Zimmerman, 1978).

Tindakan manajer dalam memilih metode akuntansi tertentu sangat dipengaruhi oleh motivasi dibalik tindakan tersebut. Deegan (2006) menyampaikan bahwa semua tindakan (termasuk tindakan manajer dalam memilih metode akuntansi) sarat dengan kepentingan pribadi, bahkan tindakan oportunis. Tindakan oportunis ini salah satunya adalah dengan memanfaatkan diskresi akrual yang dilakukan oleh manajer. Tindakan oportunis yang dimaksud adalah tindakan yang mampu meningkatkan kesejahteraan manajer (P. Healy, 1985; P. M. Healy \& K, 1990; Heggerman \& Zmijewski, 1979; Mukhlasin, 2002, 2004; Niehaus, 1989; Robbin, Turpin, \& Polinski, 1993).

Terkait dengan Topeng Malangan ada beberapa karakteristik yang dapat mewakili dari tindakan manajer. Tindakan oportunis tampak pada karakteristik topeng yang diberi nama Bapang. Menurut Zuhri (2009) Bapang mempunyai karakteristik yang sombong, licik, ahli strategi, hipokrit, atau munafik. Tindakan ini menimbulkan "kekeruhan informasi keuangan". Laporan keuangan yang disajikan dengan metafora topeng Bapang tidak lebih dari sebuah gelembung-gelembung informasi keuangan yang dipermukaannya tampak tenang atau ditutupi oleh busabusa, tetapi di balik itu ternyata ada kekeruhan informasi keuangan. Sukoharsono and Halim (2005) menyatakan kekeruhan tersebut dapat menyesatkan penggunanya dalam pengambilan keputusan.

Dalam tari wayang topeng tokoh utama diperankan oleh Panji dari golongan satria yang memiliki karakter seperti Arjuna dalam cerita wayang. Panji ini adalah seorang digdaya yang suka bertapa dan pengabdiannya kepada orang tua sangat besar. Selain itu ada juga karakter topeng yang diperankan oleh Sekartaji, Gunungsari, dan Ragil kuning yang memiliki sifat yang baik seperti jujur, rendah hati, pemberani, dan tegas. Jika manajer memiliki sifat baik sebagaimana tokoh tersebut, maka dalam praktik akuntansi akan ditampilkan nilai-nilai yang tidak hanya mementingkan kepentingan golongan tertentu, tetapi dapat mewakili semua golongan. Gambaran topeng dari masing-masing karakter tampak tampak pada Gambar 1. 


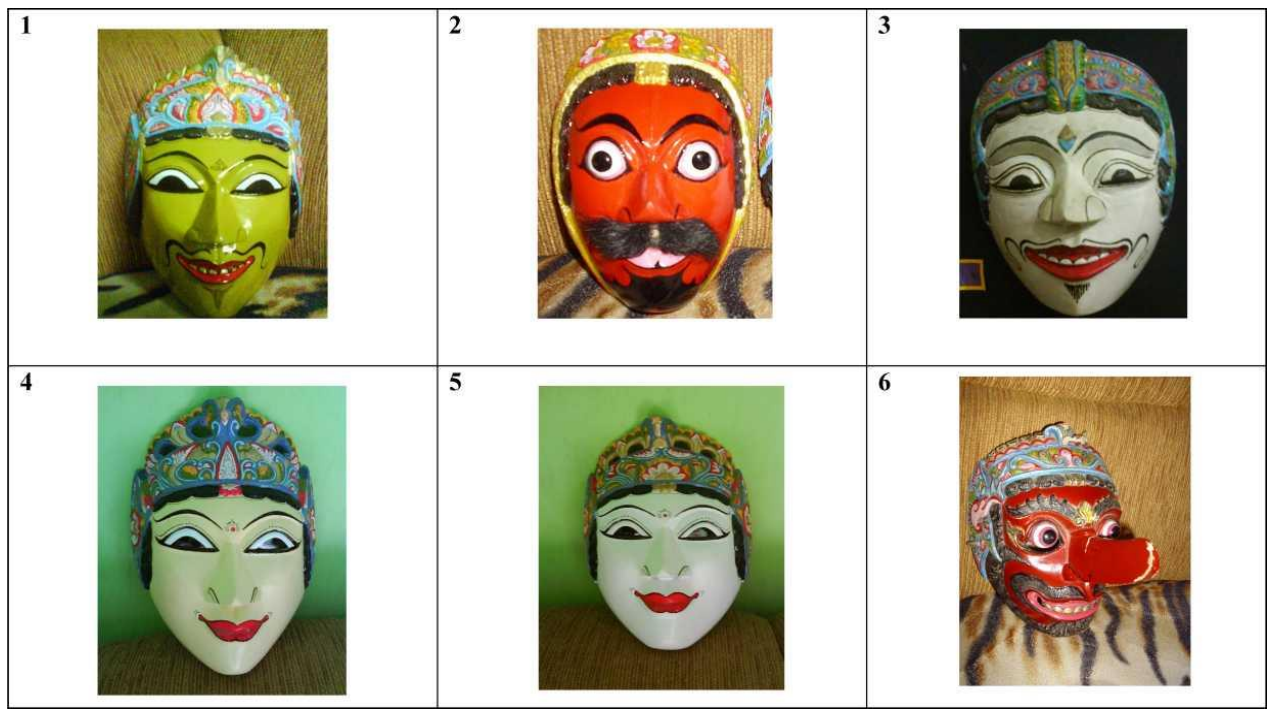

Gambar 1. Bentuk dan karakter Topeng

Sumber: (Zuhri, 2009)

Keterangan:

1) Klono (Sewandono); 2) Bapang; 3) Gunungsari; 4) Panji (Asmoro Bangun; 5) Sekar Taji, dan 6) Ragil Kuning

\section{HASIL DAN PEMBAHASAN}

Pengintaian dari Balik Tari Topeng Malangan. Tari topeng menjadi media komunikasi penyampaian contoh teladan bagi masyarakat dalam menjalani kehidupan sehari-hari. Tari topeng merupakan kesenian khas Indonesia yang sudah ada semenjak zaman nenek moyang. Hampir semua daerah di Indonesia memiliki sejarah tentang pertunjukan menggunakan topeng. Di Jawa pertunjukan seni tari topeng telah dikenal sejak tahun 762 Saka (840 Masehi). Hal ini dijelaskan dalam prasasti Jaha dan kala itu topeng dijadikan sebagai sarana utama ritual pemujaan dan pertunjukan yang dikenal dengan istilah Atapukan. Istilah lain yang juga sering digunakan yaitu istilah Raket, Manapel, dan Popok. Dari beberapa istilah tersebut semuanya menjurus pada satu arti yaitu berarti penutup wajah yang pada saat ini juga bisa disamakan dengan arti kata "Topeng" (Jason, 2003). Selain cerita rakyat berupa dongeng yang menggunakan tutur kata dan narasi, strategi lain yang bisa digunakan sebagai media komunikasi untuk membumikan nilai-nilai dalam masyarakat adalah gerak tari. Daerah Malangjuga memiliki tarian dengan menggunakan topeng, yang biasa disebut dengan wayang topeng atau tari topeng Malangan.

Seiring berjalannya waktu dan ketertatihan eksistensi budaya tradisional, kesenian ini perlahan-lahan hilang dan berangsur-angsur tergusur oleh arus budaya modern. Hal ini disebabkan kurangnya sumber sejarah yang mencatat sepak terjang kesenian ini secara pasti, sampai pada akhirnya dilakukan pencatatan sejarah oleh Dr. Th. Pigeaud pada tahun 1930an yang menyebutkan bahwa kesenian ini merupakan salah satu pertunjukan tradisional populer khas Jawa yang berada di wilayah Malang (Jason, 2003). Tari ini adalah simbol bagi sifat manusia, karena itu banyak model topeng yang menggambarkan situasi yang berbeda, seperti, menangis, tertawa, sedih, malu, dan sebagainya. Wayang topeng di Malang, khususnya di Dusun Kedungmonggo yang merupakan salah satu fenomena sosial yang memiliki kaitan dengan struktur sosial masyarakatnya, hal ini dipahami sebagai realitas yang tersusun dari satuan-satuan unit kehidupan yang bersifat kompleks serta memiliki kaitan relasi fungsional (Hidajat, 2005).

Sebagaimana halnya dengan wayang topeng, akuntansi juga memiliki kerangka sosial berupa norma-norma, nilai-nilai dan asumsi, dan memiliki sifat kompleks yang saling terkait dalam bentuk relasi fungsional untuk mengambil kebijakan yang tepat atau perilaku ekonomis yang bisa diterima (Budiman, 1999; 
Hofstede et al., 2010). Berdasarkan hasil wawancara dengan budayawan Malang (bapak Sunari) sebagaimana yang telah dijelaskan pada pembahasan terdahulu tentang sekilas budaya Malang maka berikut ini diuraikan makna akuntansi yang berhasil dikumpulkan berdasarkan cerita tentang tari topeng Malangan.

Tontonan dalam akuntansi dapat dilihat oleh penggunanya melalui laporan keuangan. Laporan keuangan disusun dan disajikan atau dipertontonkan kepada pihak-pihak yang berkepentingan seperti investor, pemerintah, masyarakat, dan manajemen perusahaan(Hidajat, 2005). Fenomena dalam penokohan wayang topeng Malang dapat disimak oleh keberadaan kesepasangan yang disebut kesetangkupan. Pada pagelaran wayang topeng tokoh yang ditampilkan selalu berpasangan atau istilah yang sering digunakan adalah "kupu tarung" antara lelaki (Panji asmarabangun) dan perempuan (candrakirana), hal ini disimbolkan sebagai rembulan dan matahari (Hidajat, 2005). Kondisi ini jika dikaitkan dengan Neraca (salah satu bentuk laporan keuangan), tampak padakeseimbangan debet dan kredit, dimana sebelah debet disajikan asset dan di sebelah kredit disajikan utang dan modal yang dalam persamaan akuntansi kondisi aset $=$ utang + modal.

Selanjutnya dalam pagelaran wayang topeng juga ditentukan berdasarkan saat (waktu) yang perhitungannya didasarkan pada jumlah hari dalam satu minggu yang disebut saptawara dan jumlah hari pasaran yaitu pancawara (Hidajat, 2005). Hal ini jika dikaitkan dengan laporan keuangan tampak pada penyajian laporan keuangan yang jugamemiliki periode waktu pelaporan (periodisasi akuntansi). Ketepatwaktuan pelaporan berhubungan dengan relevansi, karenarelevansidalam laporan keuangan harus dapat mempengaruhi keputusan ekonomi para penggunanya. Tepat waktu meliputi penyediaan informasi laporan keuangan dalam jangka waktu pengambilan Keputusan. Jika terdapat penundaan yang tidak semestinya dalam pelaporan, maka informasi yang dihasilkan akan kehilangan relevansinya (Pilliang, 2003). Manajemen mungkin perlu menyeimbangkan secara relatif antara pelaporan tepat waktu dan penyediaan informasi yang andal. Untuk mencapai keseimbangan antara relevansi dan keandalan, maka pertimbangan utama adalah bagaimana yang terbaik untuk memenuhi kebutuhan pengguna dalam mengambil Keputusan ekonomi.

Tatanan. Dalam tari topeng Malangan memiliki aturan-aturan yang harus diikuti oleh pemeran sesuai dengan karakter dan cerita yang dimainkan. Aturanaturan ini memuat nilai-nilai dan sikap yang perlu menjadi bahan perenungan yaitu adanya sikap pro sosial dan sikap dominan. Dalam tatanan penyajian laporan keuangan juga memuat aturan-aturan yang harus diikuti/ditaati berdasarkan standar akuntansi yang berlaku umum seperti standar akuntansi keuangan (SAK) dan SAK_ETAP. Penyajian laporan keuangan untuk kepentingan orang banyak (sosial) di antaranya adalah investor, pemerintah, masyarakat, ataupun pihak manajemen perusahaan. Kepentingan sosial ini dilindungi oleh pihak-pihak yang mendominasi kepentingan kepemilikan seperti KAP Internasional (diwakili oleh Big Four) dengan menetapkan standar sesuai dengan agenda global mereka.

Gambar 2.

Dalam pagelaran tari topeng ada urut-urutan yang sudah baku sebagaimana 


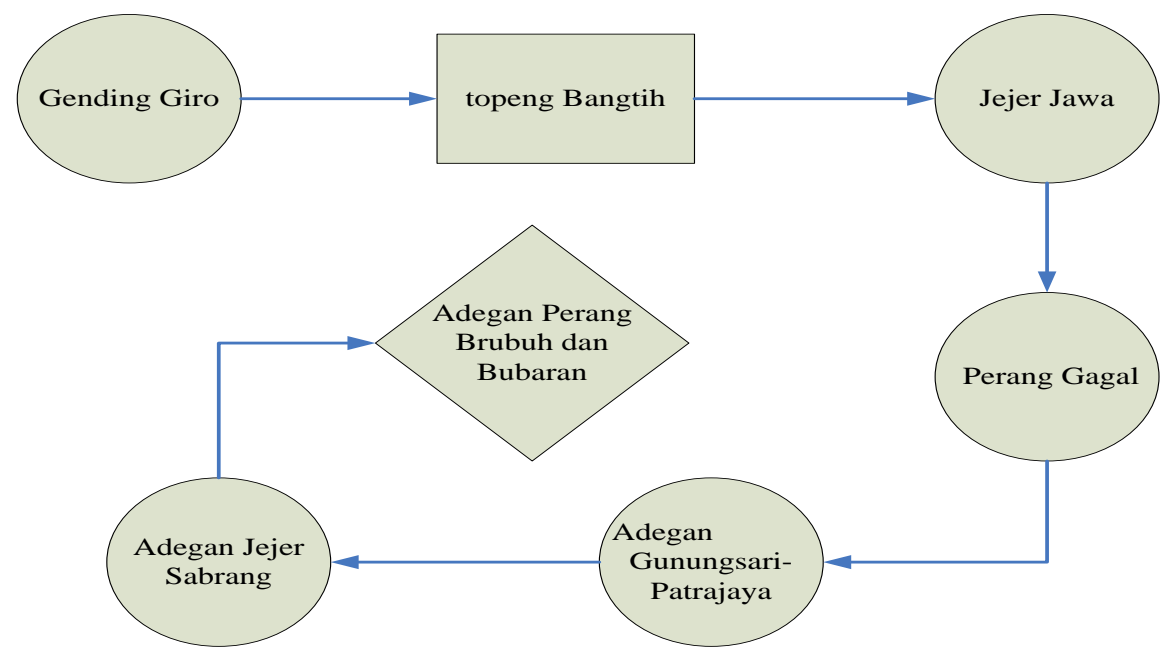

Gambar 2. Urutan Pagelaran Wayang Topeng Sumber: Supriyanto dan Adi Pramono (dalam Hidajat, 2005)

Berdasarkan gambar 1 di atas, jika dikaitkan dengan akuntansi maka untuk menyusun dan menyajikan laporan keuangan juga ada tahapan-tahapan yang harus dilalui dan disebut dengan siklus akuntansi. Gambar siklus akuntansi tampak pada Gambar 3.

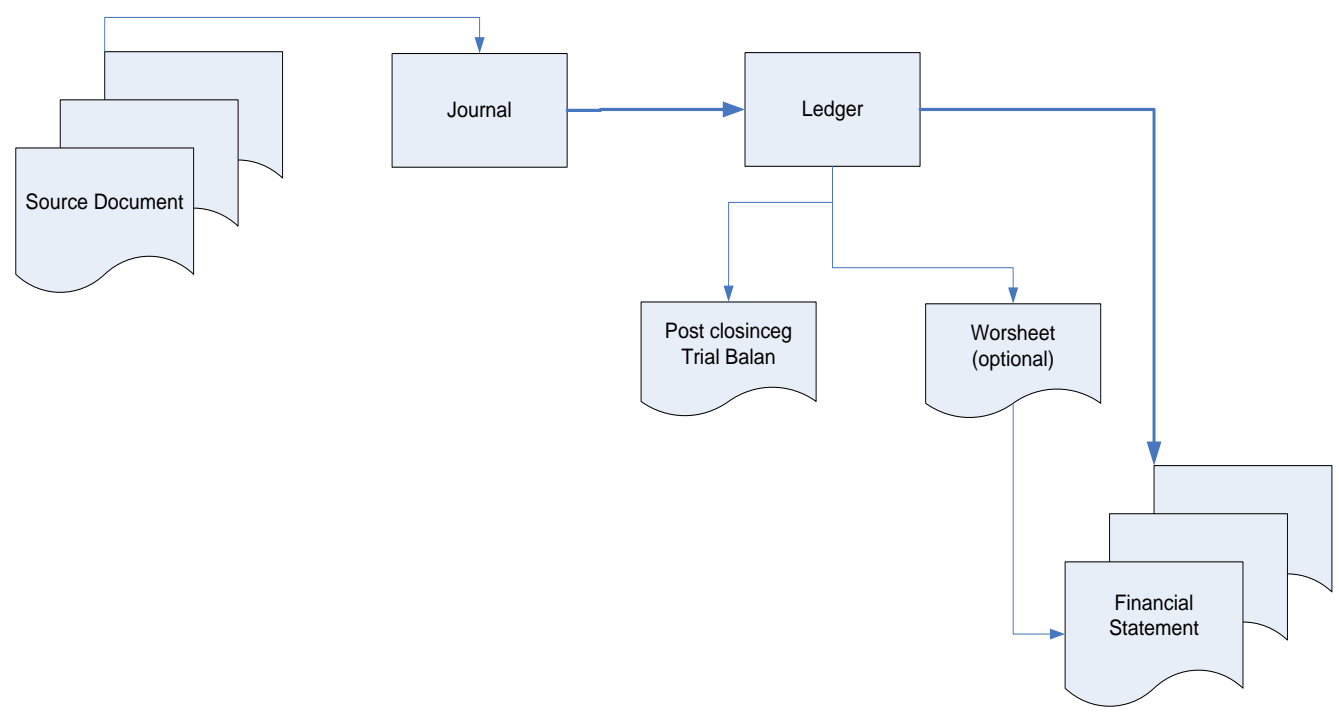

Gambar 3. Siklus Akuntansi

Sumber :(Warren, Reeve, \& Duchac, 2012, p. 141)

Untuk menyusun laporan keuangan ada karakteristik tertentu yang harus diikuti diantaranya adalah (1) dapat dipahami, (2) relevan, dan (3) substansi mengungguli bentuk. Jika laporan keuangan yang disajikan harus dapat dipahami oleh penggunanya, maka dalam pagelaran tari topeng demikian pula. Tari topeng yang digelar juga dapat dipahami maknanya oleh penonton karena alur cerita serta tokoh-tokoh yang memainkan peran masing-masing menarik minat penonton untuk menyaksikannya. Selain itu pagelaran tari topeng masih relevan disajikan pada era saat ini, meskipun tarian ini sudah ada sejak abad VII (Minarto, 2008). Sedangkan makna substansi mengungguli bentuk dalam karakteristik laporan keuangan, tampak pula pada wayang topeng. Topeng merupakan simbol yang diperuntukkan bagi penonton untuk memahami karakter dari setiap lakon. Topeng disajikan untuk mempertegas karakter lakon. 
Dari uraian tentang tari topeng Malangan yang dikaitkan dengan akuntansi dapat dirangkum dalam tabel berikut.

Tabel 1. Makna Akuntansi Di Balik Tari Topeng

\begin{tabular}{|c|c|}
\hline Nomor & Topeng \\
\hline \multirow[t]{3}{*}{1.} & $\begin{array}{l}\text { tontonan.; tari topeng } \\
\text { merupakan karya seni } \\
\text { tarian yang dipertunjuk } \\
\text { untuk menghibur orang } \\
\text { banyak. }\end{array}$ \\
\hline & a. Sikap pro sosial \\
\hline & $\begin{array}{l}\text { b. Sikap dominan } \\
\text { 1) Asertif } \\
\text { 2) Agresif } \\
\text { 3) Labelisasi nama } \\
\text { daerah/orang }\end{array}$ \\
\hline
\end{tabular}

2. Tatanan; dalam tarian dibutuhkan aturan atau scenario tentang lakon para actor sesuai alur cerita.

2. Laporan keuangan ditujukan bagi pihak-pihak yang berkepentingan seperti investor, pemerintah, dll

3. Kewajiban perusahaan dalam menyusun dan menyajikan laporan keuangan ditetapkan berdasarkan IFRS, PSAK, atau pun SAK-ETAP. Hal ini menunjukkan adanya dominasi standar yang ditetapkan bagi perusahaan untuk menyusun laporan keuangan.

4. Asertif dalam penyajian laporan keuangan dapat ditunjukkan dengan adanya pihak-pihak yang menyajikan laporan itu tidak sesuai dengan kondisi yang sebenarnya yang ditujukan untuk kepentingan pribadi.

5. Penyusun laporan keuangan harus bersifat agresif, dalam artian mereka tidak perlu ditagih untuk memberikan laporan atas hasil usaha yang dilakukan, karena hal ini untuk kepentingan perusahaan sendiri.

6. Dalam laporan keuangan juga ditemui adanya label-label seperti Aset, Utang, dan Modal.

7. Sebagai tatanan; dalam menyusun laporan keuangan juga diperlukan aturan dalam penyajiannya yaitu SAK dan SAK-ETAP

3. Tuntunan; dalam setiap kisah pada pagelaran tari topeng ada nilai-nilai yang ingin disampaikan kepada penonton.

Sebagai tuntunan; laporan keuangan harus pula mengandung tata nilai atau norma yang diperlukan untuk menyusun laporan keuangan.

\section{SIMPULAN}

Tari topeng mengandung nilai-nilai moral melalui simulasi, mitos, dan symbolsimbol. Tari ini adalah sismbol bagi sifat manusia, karena itu banyak model topel yang menggambarkan situasi yang berbeda, seperti menangis, tertawa, sedih, malu, dan sebainya. Tari wayang topeng merupakan tontonan, tuntunan, dan tatanan. Sebagaimana dengan tari Topeng, maka dalam akuntansi juga memiliki konsep tontonan, tatanan, dan tuntunan. Dikatakan sebagai tontonan karena akuntansi disajikan dalam bentuk laporan keuangan yang disajikan untuk kepentingan 
penggunanya. Sebagai tatanan, dalam menyusun laporan keuangan ada aturan dan norma-norma yang harus diikuti, sebagai tuntunan, laporan keuangan juga mengandung nilai-nilai yang harus diikuti oleh penyusun laporan keuangan.

Karakteristik wayang topeng juga memiliki makna yang berhubungan dengan teori agency, yaitu ada tokoh baik dan ada tokoh jelek. Begitu juga di konsep teory agency, yang biasanya manajer cenderung berpihak kepada kepentingan golongan, yang dalam pagelaran wayang topeng ditokohkan oleh Bapang dengan sifat yang licik dan sombong sehingga cenderung mementingkan diri sendiri. Lain halnya jika manajer meniru sifat baik Panji, dimana laporan keuangan disajikan sesuai ketentuan yang dapat dimanfaatkan oleh semua golongan, maka keputusan yang diambil tentu tidak akan menyesatkan.

\section{DAFTAR RUJUKAN}

Aamaah. (2011, 20 Maret ). Sekilas mengenai Malang Retrieved 9 Mei 2014, from http://www.malang-guidance.com/sekilas-mengenai-malang/

Baudrillard, Jean. (1983). Simulation. New York: Semiotext(e).

Budiman, K. (1999). Kosa Semiotika (Cetakan 1 ed.). Yogyakarta.

Deegan, C. (2006). Financial Accounting Theory (2 ed.). Australia: Mc. Graw-Hill Australia Pty. Ltd.

Healy, P. (1985). The Impact of Bonus Schemes on The Selection of Accounting Principles. Journal of Accounting and Economics, 7, 85-107.

Healy, P. M., \& K, Palepu. (1990). The Effectiveness Of Accounting-Based Dividend Covenant. Journal of Accounting and Economics, 2(1), 52-76.

Heggerman, R. L., \& Zmijewski, M. Y. (1979). Some Economic Determinants of Accounting Policy Choice. Journal of Accounting and Economics, 12, 146-161.

Hidajat, Robby. (2005). Struktur, Simbol, dan Makna Wayang Topeng Malang. Bahasa dan Seni, 33( 2), 270-282.

Hofstede, Geert, Hofstede, Gert Jan, \& Minkov, Michael. (2010). Culture and Organization. Software of the Mind Intercultural Cooperation and Its Importance for Survival

Ismiyanti, F., \& Hanafi, M. (2004). Struktur Kepemilikan, Risiko, dan Kebijakan Keuangan: Analisis Persamaan Simultan. Jurnal Ekonomi dan Bisnis indonesia, $19(2), 176-196$.

Jason (Producer). (2003, 11 Mei 2014). Mengenal Tari Topeng Malang. Retrieved from http://topengmalangofmalang.blogspot.com/

Jensen, Michael C., \& Meckling, William H. (1976). Theory of The Firm: Managerial Behavior, Agency Costs and Ownership Structure Journal of Financial Economics 3(4), 305-360.

Ludigdo, Unti (2005). Pemahaman Strukturasi atas Praktik Etika di Sebuah Kantor Akuntan Publik. (Ph.D), Universitas Brawijaya., Malang.

Macintosh, Norman B. (2003). From Rationality to Hyperreality: Paradigm Poker. International Review of Financial Analysis, 12, 453-456.

Minarto, Soerjo Wido. (2008). Struktur Simbolik Tari Topeng Patih Pada Pertunjukan Dramatari Wayang Topeng Malang Di Dusun Kedungmonggo Desa Karangpandan Kecamatan Pakisaji Kabupaten Malang. (S-2), Universitas Negeri Semarang.

Mukhlasin. (2002). Analisis Pemilihan Metode Akuntansi Persediaan dan Pengaruhnya terhadap Earning Price Ratio. Paper presented at the Simposium Nasional Akuntansi V, Semarang.

Mukhlasin. (2004). Analisis Kebijakan AKuntansi dan Pengaruhnya terhadap Nilai Perusahaan. Jurnal Akuntansi, Auditing dan Keuangan Balance, 1(2), 1-22.

Niehaus, G. R. (1989). Ownership Structure and Inventory Method Choice. The Accounting Review, 269-284.

Piliang, Yasraf Amir. (1999). Sebuah Dunia yang Dilipat; Realitas Kebudayaan Menjelang Milenium Ketiga dan Matinya Posmodernisme. Bandung: Mizan.

Pilliang, Yasraf Amir. (2003). Hiper Semiotika: Tafsir Kultural Studies atas Matinya Makna. Bandung: Jala Sutra. 
Putri, I Gusti Ayu Made Asri Dwija. (2011). Dampak Good Corporate Governance dan Budaya Organisasi pada Pengaruh Kebijakan Dividen terhadap Manajemen Laba serta Konsekuensinya pada Nilai Perusahaan. (S3), Universitas Brawijaya, Malang.

Ricoeur, P. (2006). Hermenetika Ilmu Sosial (Muhammad Syukri, Trans. cetakan 1 ed.). Yogyakarta: Kreasi Wacana.

Riduwan, Akhmad, Triyuwono, Iwan, Irianto, Gugus, \& Ludigdo, Unti. (2009). Semiotika Laba Akuntansi: Studi Kritikal - Posmodernis Derridean. Paper presented at the Simposium Nasional Akuntansi (SNA) XII, Samarinda.

Ritzer, George, \& Goodman, Douglas J. (2012). Teori Sosiolog; Dari Teori Sosiologi Klasik Sampai Perkembangan Mutakhir Teori Sosial Posmodern. Bantul: Kreasi Wacana Offset.

Robbin, W. A., Turpin, R., \& Polinski, P. (1993). Economic Incentives and Accounting Choice Strategy by Nonprofit Hospitals. Financial Accountability and Management., 9(3), 159-175.

Rsm. (2013). Kunjungan Wisatawan Asing Naik 300 \% Retrieved 21 May, 2014, from http://www.memoarema.com/24600/kunjungan-wisatawan-asing-naik300.html

Spradley, J.P. (1997). Metode Ethnografi. Yogyakarta: Tiara Wacana.

Sukoharsono, Eko Ganis, \& Halim, Abdul. (2005). Dialektika Kritis Laporan Keuangan atas Representasi Kinerja Perusahaan (Studi Pada Industri Food and Beverages yang Go Public di Bursa Efek Jakarta: PART 1). Jurusan Akuntansi. Universitas Brawijaya. Malang.

Sutopo, H.B. (2002). Metode Penelitian Kualitatif. Dasar Teori dan Terapannya dalam Penelitian. Surakarta: Sebelas Maret University Press.

Warren, Carl S., Reeve, James M., \& Duchac, Jonathan E. (2012). Accounting 21e ( 21 ed.). Singapore: Rob Deway.

Watts, R. L., \& Zimmerman, J. L. (1978). Toward A Positive Theory of the Determination of Accounting Standards. The Accounting Review, 53, 112-134.

Zuhri, Syaifuddin. (2009). Transformasi Belajar Sosial dalam Pertunjukan Seni Tari Topeng Malang Sanggar Asmorobangun. (S-1), Unversitas Islam Negeri Maulana Malik Ibrahim, Malang. 